\title{
Degradation of zooxanthellae and regulation of their density in hermatypic corals
}

\author{
E. A. Titlyanov ${ }^{1, *}$, T. V. Titlyanova ${ }^{1}$, V. A. Leletkin ${ }^{1}$, J. Tsukahara $^{2}$, R. van Woesik ${ }^{3}$, \\ K. Yamazato ${ }^{4}$ \\ ${ }^{1}$ Institute of Marine Biology, Far East Branch of Russian A cademy of Sciences, Vladivostok, 690041, Russia \\ ${ }^{2}$ Department of Biology, Faculty of Science, Kagoshima University, Kagoshima 80, Japan \\ ${ }^{3}$ Department of Marine Sciences, University of the Ryukyus, Senbary 1, Nishihara, Okinawa 903-01, Japan \\ ${ }^{4}$ Department of Biology and Tropical Biosphere Research Centre, University of the Ryukyus, Nishihara-cho, Okinawa 903-01, Japan
}

\begin{abstract}
This study investigated the process of zooxanthellae degradation in hermatypic corals. The number of degraded zooxanthellae in corals taken from different light conditions amounted to 1 to $6 \%$ a day, which was similar to the number of dividing zooxanthellae. Zooxanthellae degradation takes place only at night in the connecting sheet and tentacles but both at night and during the day in the gastroderm of the mesenteries. Zooxanthellae degradation continues for about $6 \mathrm{~h}$. DNA staining with DAPI (4'6-diamidino-2-phenylindole) and light, UV and electron microscopic examinations showed that zooxanthellae under degradation lost DNA, protein of pyrenoids and lipid drops. The degraded zooxanthellae particles contained 'accumulation bodies', unpacked thylakoids, starch grains and a pyrenoid starch envelope. Under starvation experimen's the number of degraded zooxanthellae in Stylophora pistillata increased in the tissue, as did their release. It is concluded that hermatypic corals are capable of regulating their zooxanthellae population by digestion and extrusion of zooxanthellae remnants
\end{abstract}

KEY WORDS: Hermatypic corals - Zooxanthellae - Degradation Digestion Regulation density

\section{INTRODUCTION}

Population densities of symbiotic algae in host invertebrates can be maintained for invariably long periods of time (Pardy \& Muscatine 1973, Pardy 1974, Pool 1976, 1979, Muscatine \& Pool 1979). A possible mechanism relating to the regulation of algal numbers is that host cells divide in 'synchrony' with the algal populations (Pardy 1974, Muscatine et al. 1985, Trench 1987). However, it was shown by Muscatine et al. (1985) in the hermatypic coral Stylophora pistillata that the growth rate of zooxanthellae was higher than the growth rate of polyps. McAuley (1994) also expressed the opposite opinion: 'in almost every type of algal/ invertebrate symbiosis the maximum growth rate of host cells is much lower than the maximum growth rate of the smaller algal symbionts'. If we accept that host

·E-mail: faribm@visenet.iasnet.com cells divide in 'synchrony' with the algal population (Trench 1987), algal regulation in the host tissue may involve (1) the host cell eliminating excess algae by exocytosis or digestion (Reimer 1971, Muscatine et al. 1985. Trench 1987, Gates et al. 1992, Buddemeier \& Fautin 1993), (2) the host controlling the algal population by prohibiting algal division (Trench 1987, Cook \& Fitt 1990, Fitt \& Cook 1990, McAuley 1994), and for (3) inhibition or stimulation of algal growth by host cells changing the supply of nutrients to the symbiont, or the production of a growth-inhibiting or growthstimulating compound (Muscatine \& Pool 1979, McAuley 1985, 1994)

Changes in symbiont densities may be prompted by environmental cues. At times it is a slow process, induced by light adaptation or seasonal changes (Titlyanov et al. 1983, Muller-Parker 1987), at other times a rapid decrease of symbionts is evident for hosts under stress. The main way a host responds to stress is tinrough the expulsion of living zooxanthellae cells 
(Muscatine \& Pool 1979, Glider 1983, Steen \& Muscatine 1987, Gates et al. 1992). For instance, expulsion of zooxanthellae was evident for Aiptasia tagetes (sea anemone) under: sustained bright light (Steele 1976), and exocytosis took place in Aiptasia pulchella held in total darkness (Muller-Parker 1984) and in darkness with starvation (Steen \& Muscatine 1987). In hermatypic corals, unusually high or low water temperatures induce zooxanthellae release (Yamazato 1981, Coles \& Fadlallah 1990, Gates 1990, Glynn 1990, Williams \& Bunkley-Williams 1990, Brown et al. 1995), as do low salinities (Goreau 1964, Coles \& Jokiel 1978, Van Woesik et al. 1995)

It is generally regarded that under normal conditions symbiont density can be regulated by expulsion of zooxanthellae (Taylor 1969, Steele 1977, Trench 1987). However, to date this regulatory mechanism has been found only in sea anemones (Steele 1976. Steen \& Muscatine 1987). Hermatypic corals, under normal circumstances, can expel 0.1 to $1.0 \%$ of their algal standing stock every day (Hoegh-Guldberg et al. 1987, Stimpson \& Kinzie 1991). Corals with this rate of zooxanthellae expulsion are not likely to regulate their symbiont population by expulsion because the release rate of healthy zooxanthellae is almost an order of magnitude lower than the replenishment rate (mitotic index from 0.5 to $10 \%$ ) (Muscatine et al. 1985, HoeghGuldberg \& Smith 1989, and the present paper). On this basis we can suppose that in hermatypic corals the expulsion process of healthy zooxanthellae is not the mechanism that regulates the algal population density.

The digestion of symbionts is a possible mechanism that regulates symbiont density in invertebrates under normal conditions (Muscatine \& Pool 1979, Muscatine et al. 1985, Hoegh-Guldberg et al. 1987, Trench 1987). The sea anemone Phyllactis flosculifera (Actiniaria) is capable of 'farming' its zooxanthellae which it uses as a nutritive source (Steele \& Goreau 1977). Recently, Fitt \& Cook (1990) found 'moribund' zooxanthellae in digestive cells of Myrionema ambionense (marine hydroid) which were subjected to lysosomal attack, mainly at night when phagolysosomes are common in the digestive cells. Cassiopea xamachana (jellyfish) in the polyp (scyphistoma) stage is capable of digesting a small portion of phagocytotically intaken algae (Symbiodinium microadriaticum) (Colley \& Trench 1985)

Symbiont digestion was first found in scleractinian corals by Boschma (1925), who observed different stages of zooxanthellae digestion in the mesenterial filaments of Astrangia danae and concluded that zooxanthellae are a part of their normal diet. However, after a series of experiments on the Great Barrier Reef of Australia, Yonge (1931) and Yonge \& Nichols (1931) concluded that the Madreporaria (Scleractinia) do not utilize plants as food and stated that zooxanthellae are only commensals, without any nutritive value for corals. In the vast literature devoted to interactions of zooxanthellae and polyps (Smith et al. 1969, Taylor 1969, Trench 1987. Sorokin 1990, McAuley 1994) it is usual to find statements like 'the question of digestion of algae by host remains controversial and problematic' (e.g. Trench 1987).

Our interests were directed towards the study of zaoxanthellae degradation in hermatypic coral tissue when recent investigations on the adaptation of algae population densities under different light regimes revealed significant amounts of degraded zooxanthellae. In this paper we will describe a series of experiments conducted on 8 hermatypic corals (mainly Stylophora pistillata), and outline observations on zooxanthellae regulation in terms of proliferation, digestion and expulsion by the host.

\section{MATERIALS AND METHODS}

Collection and maintenance of specimens. From March to June 1995, colonies of Millepora tenella Ortmann 1892, Montipora digitata (Dana 1846), Pocillopora damicomis (Linnaeus 1758), Porites cylindrica (Dana 1846), Porites horizontalata (Hoffmeister 1925), Seriatopora caliendrum (Ehrenberg 1834), Seriatopora hystrix (Dana 1846) and Stylophora pistillata (Esper 1797) were collected from different shallow water habitats near Sesoko Station, Tropical Biosphere Research Centre, University of Ryukyus (Okinawa, Japan). Coral colonies were removed from the substrate and immediately placed in a running sea water aquarium. Branch tips ( 3 to $5 \mathrm{~cm}$ length) were broken off each colony and left in these aquaria until morning. They were collected at 09:00 h the next day and all branches were either analyzed or used in physiology experiments.

Experimental design. Diurnal patterns of zooxanthellae degradation in the gastrodermis (Expt 1): Four branches, from 2 separate colonies, were placed in a 11 glass jar. Four replicate jars were maintained under aeration in an outdoor (running sea water) tank. The water temperature was 26 to $28^{\circ} \mathrm{C}$ during the day and 24 to $26^{\circ} \mathrm{C}$ at night. Incident photosynthetic active

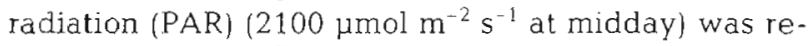
duced to 60 to $80 \%$ by grey plastic mesh. Sea water in the jars was changed twice a day at 08:00 h and 19:00 h. Diurnal patterns of zooxanthellae degradation in the polyp gastrodermis and accumulation of degraded zooxanthellae in the body cavity were studied after the 3 rd day in the aquaria. Two branches (1 branch from each colony) were analyzed every $3 \mathrm{~h}$ during the day. The experiment was replicated twice with analogous results; only 1 set of results is presented. 
Temporal release of healthy (h.z.) and degraded zooxanthellae (d.z.) by coral colonies (Expt 2): Small coral colonies (diameters about $10 \mathrm{~cm}$ ) of Stylophora pistillata, Seriatopora caliendrum and Porites horizontalata were placed separately into 2 I glass jars and maintained as described for Expt 1 . The released zooxanthellae were collected and counted twice a day, when sea water was changed. Zooxanthellae release was studied for $10 \mathrm{~d}$. The experiment was replicated 3 times with analogous results; the results of 1 experiment are presented.

Diurnal patterns of accumulation of degraded zooxanthellae particles (d.z.p.) (Expt 2a): On the 5th $\mathrm{d}$ of Expt 2, we collected $200 \mathrm{ml}$ of water from the jars every $2 \mathrm{~h}$ (water was subsequently replaced). This was filtered (with Millepora filter Type JH $0.45 \mu \mathrm{m}$ ), and the number of individual d.z.p. and d.z.p. in pellets was counted.

Diurnal patterns of degraded zooxanthellae released by coral branches (Expt 3): Six branches from different colonies of Stylophora pistillata and Seriatopora caliendrum were placed separately in 21 glass jars. Maintenance of the specimens was as described in Expt 1. The release rates of d.z.p. were studied for $3 \mathrm{~d}$. $200 \mathrm{ml}$ water samples were taken every $3 \mathrm{~h}$ and analyzed as in Expt 2a. The experiment was replicated 3 times and results were analogous.

Starvation experiment (Expt 4): External branch tips (4 cm length) were taken from the upper portions of 3 Stylophora pistillata colonies that were found in shaded habitats with 10 to $20 \%$ of surface irradiance Six branches were placed in 21 jars with glass microfibre filtered (GF/B, $1 \mu \mathrm{m})$ sea water. There were 4 replicate jars. Morpho-physiological analyses of the coral branches were conducted on the 1st, 4th, 8th, 12 th, 24th and 36th days of the experiment. One branch from each colony was analysed during each sampling event. The experiment was replicated twice with analogous results.

Measurement techniques. Light microscopy of living tissues: Small pieces of living tissue were detached from the skeleton using a scalpel and were viewed under a Nikon microphoto-FXA microscope with $\times 1000$ magnification.

Light and electron microscopy investigation of zooxanthellae debris: Individual degraded zooxanthellae particles (d.z.p.) were viewed under a light microscope (magnification $\times 400$ ) and photographed directly on the filter paper. They were subsequently washed from the filter and centrifuged. The d.z.p. suspension was used for electron microscopy and prepared as follows (1) pre-fixed in 3\% glutaraldehyde in $0.1 \mathrm{M}$ phosphate buffer $\left(\mathrm{pH} \mathrm{7.4)}\right.$ ) and $0.5 \mathrm{M} \mathrm{NaCl}$ for 2 to 3 h at $4^{\circ} \mathrm{C}$; (2) rinsed 3 times with the same buffer saline solution; (3) post-fixed in $1 \% \mathrm{O}_{3} \mathrm{O}_{4}$ in the same buffer saline solution for $1 \mathrm{~h}$ at $0^{\circ} \mathrm{C} ;(4)$ rinsed once with the same buffer saline solution; (5) dehydrated with an alcohol series $(50,70,90,95,99,100 \%)$ for 15 min at each step at $0^{\circ} \mathrm{C}$; (6) embedded with Spurr resin; (7) cut into 70 to $80 \mathrm{~nm}$ sections; (8) stained with uranyl acetate and lead citrate (according to Reynolds 1963).

Zooxanthellae release from corals, their analyses and photography: Living tissue was removed with a Water-Pik (Johannes \& Wiebe 1970). The samples were taken for determinining the number of healthy zooxanthellae (h.z.) using a hematocytometer, the degraded zooxanthellae frequency (DZF), the proliferating zooxanthellae freguency (PZF), the diameters of h.z. and d.z. and the chlorophyll content and for photography. The number of zooxanthellae was calculated per polyp and per coral area. First, the number of polyps per branch was counted, second the coral's surface area was determined by a modified wax method (Sorokin 1990). The means for the DZF were calculated on the basis of 30 microscope fields $(\times 400)$. Dividing cells were any cells between the point of initial appearance of cell walls in the mother cells to the formation of their own cell envelope in the daughter cells. The h.z. and d.z. diameters were measured with an ocular-micrometer and their sizes were calculated using the volume formula for a sphere Chlorophylis $a$ and $c$ were extracted from zooxanthellae or d.z.p. (non-distinctive) with a $90 \%$ aqueous solution of acetone, and refrigerated for $2 \mathrm{~d}$. Concentrations were measured by a Hitachi U-2000 spectrophotometer. The amount of chl $a$ and $c$ was calculated using the Jeffrey \& Humphrey (1975) formula. Healthy and degraded zooxanthellae, in different stages of degradation, were photographed with a light microscope $(\times 1000)$.

Counting h.z. and d.z. numbers in different gastroderm tissue: Mid portions of coral branches (ca 100 polyps) were placed into $5 \%$ HCL until the skeleton was dissolved, then washed in sea water and examined under $\times 400$ magnification. Gastroderm cell layers of the connecting sheet and tentacles were viewed through the ectodermis. Gastroderm cells of the mesenteries were observed from the inner part of the polyp tissue. The number of h.z. and d.z. were counted (with a fixed focus) and the diameters of h.z. and $d . z$. were measured. Means were calculated from 30 microscopy fields and 2 pieces of coral tissue.

Determination of d.z.p. number in the body cavity: The number of d.z.p. were determined by drawing up $0.01 \mathrm{ml}$ of body cavity liquid (the needle was inserted into the polyp pharynx). The contents of 40 body cavities, diluted with sea water to $1 \mathrm{ml}$, were analyzed for d.z.p. concentration using a haemocytometer. The number of d.z.p. per polyp was calculated from these extractions. 
Staining of DNA with DAPI: In order to reveal localized DNA in the nuclei, a solution of $0.5 \mathrm{mg} \mathrm{m}^{-1}$ DAPI (4'6-diamidino-2-phenylindole; Sigma Chemical Co.) was prepared according to Hull et al. (1982). H.z., d.z. and d.z.p. were derived by centrifugation, fixed and bleached in a mixture of concentrated acetic acid and a $90 \%$ aqueous solution of acetone (1:10), and stained with DAPI $\left(15 \mathrm{~min}, 24^{\circ} \mathrm{C}\right)$.

Photosynthetic active radiation (PAR): The availability of PAR on the water surface, under water in the natural habitat, and in the experimental jars was measured with an underwater photometer LI-Cor, Inc. Model LI-185 B.

\section{RESULTS}

\section{Zooxanthellae proliferation and degradation in corals from different light habitats}

The hermatypic corals Porites cylindrica, Seriatopora caliendrum and Stylophora pistillata taken from. shaded habitats had 10 to $100 \%$ more zooxanthellae than those taken from well lit habitats (Table 1), although the number of zooxanthellae was approximately equal in Montipora digitata and Seriatopora hystrix in both habitats. Proliferating zooxanthellae frequency (PZF) fluctuated from $0.3 \pm 0.1$ to $5.9 \pm 0.9 \%$ in all species examined. In most cases it was lower in corals taken from shaded habitats. Degraded zooxanthellae frequency (DZF) varied from $1.1 \pm 0.3$ to $7.6 \pm 0.9 \%$ and was lower for shaded colonies. The largest zooxanthellae (an average $13.8 \pm 0.3 \mu \mathrm{m}$ in diameter) were found in Millepora tenella, and the smallest in both species of Seriatopora (an average $8.6 \pm 0.1 \mu \mathrm{m}$ in diameter); a relation consistent for degraded zooxanthellae. In all species examined the average diameter of $d . z$. amounted to approximately $50 \%$ of the h.z. diameter

Often, d.z. were in different stages of degradation (Table 1, Fig. 1A). At the first stage, the cells differ from h.z., and appear browner and more dense, and support small droplets in the cell (Fig. 1A). At the second stage, the zooxanthellae take on a deep brown colour, the cell wall is partly destroyed, and the chloroplast looks compressed. At this stage the cell is generally surrounded by droplets. Completely degenerated zooxanthellae appear orange to deep brown, and support starch-like globules. Dividing cells were at times found among the degraded zooxanthellae (Fig. 1A).

\section{Completely degraded zooxanthellae particles (d.z.p.)}

Released d.z.p. had either a round or irregular shape (Fig. 1B), their diameters were less than $50 \%$ of the h.z. diameters, and their volume amounted to $1 / 8$ of the h.z. volume. The d.z.p. were orange to deep brown in colour. Intact colonies of Stylophora pistillata, Seriatopora caliendrum and Porites horizontalata released not only single and double particles (Fig. 1C), but also variously shaped pellets, at times containing 1000s of d.z.p. (Fig. 1B). In Expts 2 and $2 a$, the pellets consisted of $99 \%$ d.z.p., and less than $1 \%$ h.z. The pellets were released irregularly. Sometimes the released pellets had a small number of d.z.p. and were largely mucus and h.z.

Under a light microscope an 'accumulation body', a chloroplast and pyrenoid remnants were observed in d.z.p. Under. UV light the yellow 'accumulation body'

Table 1 Density of zooxanthellae (z) population, daytime degraded zooxanthellae frequency (DZF) and proliferating zooxanthellae frequency (PZF), and diameters of healthy and degraded zooxanthellae (h.z. and d.z.) for corals from different light habitat.s. Values are means $\pm \mathrm{SD}$ of 6 to 8 measurements (branches)

\begin{tabular}{|c|c|c|c|c|c|c|c|}
\hline Species & $\begin{array}{c}\text { Surface } \\
\text { irradiance } \%\end{array}$ & $\begin{array}{l}10^{\mathrm{h}} \mathrm{z} \cdot \mathrm{cm}^{-2} \\
\text { coral surface }\end{array}$ & $\begin{array}{l}10^{3} z \text { per } \\
\text { polyp }\end{array}$ & $\begin{array}{l}\text { PZF (day- } \\
\text { time \%) }\end{array}$ & $\begin{array}{l}\text { DZF (day- } \\
\text { time \%) }\end{array}$ & $\begin{array}{l}\text { Diameter } \\
\text { h.z. }(\mu \mathrm{m})\end{array}$ & $\begin{array}{l}\text { Diameter } \\
\text { d.z. }(\mu \mathrm{m})\end{array}$ \\
\hline Millepora tenella & $60-80$ & $0.37 \pm 0.05$ & $11.6 \pm 1.4$ & $2.0 \pm 0.8$ & $3.2 \pm 0.7$ & $13.8 \pm 0.3$ & $6.4 \pm 0.7$ \\
\hline Montipora digitata & $\begin{array}{l}60-80 \\
15-20\end{array}$ & $\begin{array}{l}1.40 \pm 0.21 \\
1.38 \pm 0.19\end{array}$ & $\begin{array}{l}23.0 \pm 7.4 \\
20.6 \pm 2.3\end{array}$ & $\begin{array}{l}3.1 \pm 1.8 \\
0.3 \pm 0.1\end{array}$ & $\begin{array}{l}2.8 \pm 0.9 \\
1.1 \pm 0.3\end{array}$ & $\begin{array}{l}11.0 \pm 0.8 \\
11.4 \pm 0.6\end{array}$ & $\begin{array}{l}6.0 \pm 0.3 \\
6.0 \pm 0.6\end{array}$ \\
\hline Pocillopora damicornis & $60-80$ & $166 \pm 0.48$ & $24.6 \pm 4.4$ & $3.2 \pm 1.3$ & $4.6 \pm 1.7$ & $11.0 \pm 0.3$ & $6.4 \pm 0.4$ \\
\hline Porites cylindrica & $\begin{array}{l}60-80 \\
15-20\end{array}$ & $\begin{array}{l}0.66 \pm 0.13 \\
1.19 \pm 0.21\end{array}$ & $\begin{array}{l}10.9 \pm 1.9 \\
22.1 \pm 3.2\end{array}$ & $\begin{array}{l}5.4 \pm 2.5 \\
4.1 \pm 1.3\end{array}$ & $\begin{array}{l}4.3 \pm 1.2 \\
3.1 \pm 1.0\end{array}$ & $\begin{array}{l}10.5 \pm 0.3 \\
10.6 \pm 1.0\end{array}$ & $\begin{array}{l}5.6 \pm 0.5 \\
5.9 \pm 0.7\end{array}$ \\
\hline Seriatopora caliendrum & $\begin{array}{r}60-80 \\
5-10\end{array}$ & $\begin{array}{l}1.33 \pm 0.42 \\
1.89 \pm 0.29\end{array}$ & $\begin{array}{l}23.3 \pm 4.9 \\
26.3 \pm 2.7\end{array}$ & $\begin{array}{l}4.8 \pm 1.8 \\
2.0 \pm 0.7\end{array}$ & $\begin{array}{l}7.6 \pm 0.9 \\
3.8 \pm 0.6\end{array}$ & $\begin{array}{r}10.0 \pm 0.3 \\
8.6 \pm 0.8\end{array}$ & $\begin{array}{l}5.1 \pm 0.4 \\
4.2 \pm 0.5\end{array}$ \\
\hline Seriatopora hystrix & $\begin{array}{r}60-80 \\
5-10\end{array}$ & $\begin{array}{l}1.20 \pm 0.24 \\
1.04 \pm 0.10\end{array}$ & $\begin{array}{l}19.7 \pm 3.9 \\
11.8 \pm 2.5\end{array}$ & $\begin{array}{l}5.9 \pm 0.9 \\
1.3 \pm 0.4\end{array}$ & $\begin{array}{l}5.3 \pm 0.4 \\
2.6 \pm 0.7\end{array}$ & $\begin{array}{l}9.5 \pm 0.3 \\
8.6 \pm 0.1\end{array}$ & $\begin{array}{l}4.8 \pm 0.4 \\
4.7 \pm 0.6\end{array}$ \\
\hline Stylophora pistillata & $\begin{array}{l}60-80 \\
15-25\end{array}$ & $\begin{array}{l}0.68+0.09 \\
0.90 \pm 0.14\end{array}$ & $\begin{array}{l}15.7 \pm 2.4 \\
21.8 \pm 3.7\end{array}$ & $\begin{array}{l}3.3 \pm 1.2 \\
4.3 \pm 1.2\end{array}$ & $\begin{array}{l}3.8 \pm 1.2 \\
30 \pm 0.7\end{array}$ & $\begin{array}{l}10.9 \pm 0.4 \\
10.8 \pm 0.5\end{array}$ & $\begin{array}{l}6.1 \pm 0.9 \\
5.7 \pm 0.4\end{array}$ \\
\hline
\end{tabular}




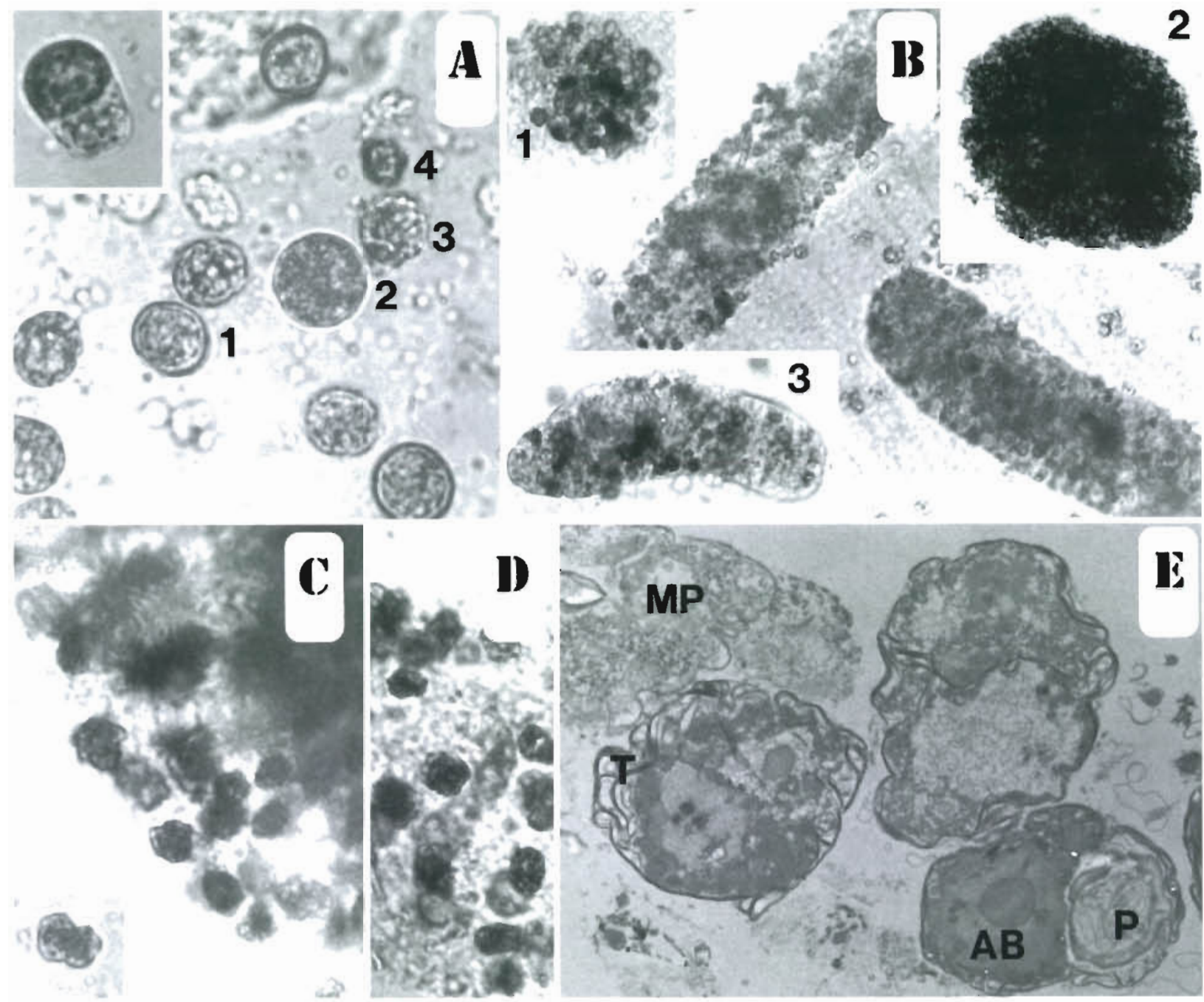

Fig. 1 Stylophora pistillata. Light and electron micrographs of degraded zooxanthellae and debris. (A) Healthy and degraded zooxanthellae in coral tissue removed from the skeleton with a Water-Pik: (1) healthy zooxanthella, (2) zooxanthella in the initial stage of degradation, (3) zooxanthella in the degradation process, (4) degraded zooxanthellae (particles). Insert shows dividing zooxanthella with degrading daughter cell. Magnification 1000x. (B) Individual degraded zooxanthellae particles (d.z.p.) and d.z.p. packed in the pellets (on the millepore filter). In the main picture are finished pellets containing about $200 \mathrm{~d} . z$.p. and individual d.z.p. under $200 \times$ magnification. Inserts show (1) the pellet in the process of formation (about 30 d.z.p.), magnification $400 \times$, (2) the pellet containing more than 4000 d.z.p., magnification $100 \times$, and (3) the pellet containıng about 50 d. z.p., magnification 200x. (C) Edge of the pellet presented in Fig. 1B, insertion 2. Insert shows a double d.z.p. Magnification 1000x. (D) Contents of the pellet presented in Fig. 1B, insertion 3. (E) Electron microscopy of degraded zooxanthellae particles. AB: 'accumulation body'; P: pyrenoid, T: thylakoids, MP: mucus particles. Magnification $6000 \times$

was similar to that found in h.z., however the chloroplast remnants fluoresced a pale red colour, as opposed to the bright red fluorescence in h.z. No DNA was observed in the stained d.z.p. (using fluorochrome DAPI). In contrast, nuclei of h.z. were stained by DAPI and fluoresced a bright blue colour. In addition d.z.p. lacked chl $c$ and, compared to h.z., chl a content was reduced by 30 to $50 \%$. Electron microscopic examinations only showed that d.z.p. contained 'accumulation bodies', unpacked thylakoids, starch grains and a pyrenoid starch cover (Fig. 1E). The nuclei, pyrenoid protein and lipid drops were lacking.

\section{Zooxanthellae degradation and proliferation in different types of tissue}

The process of zooxanthellae degradation occurs in the gastrodermal cells of the connecting sheet, tentacles and mesenteries. DZF reach their maximum at night in Stylophora pistillata (Fig. 2A). The DZF was 5 to 6 times higher in the mesenteries than in the connecting sheet and 30 times higher than in tentacles. In contrast, in $S$. pistillata tissue the d.z. density per $\mathrm{mm}^{2}$ of gastrodermal surface was highest in the connecting sheet and lowest in the tentacles (Fig. 2B). The 

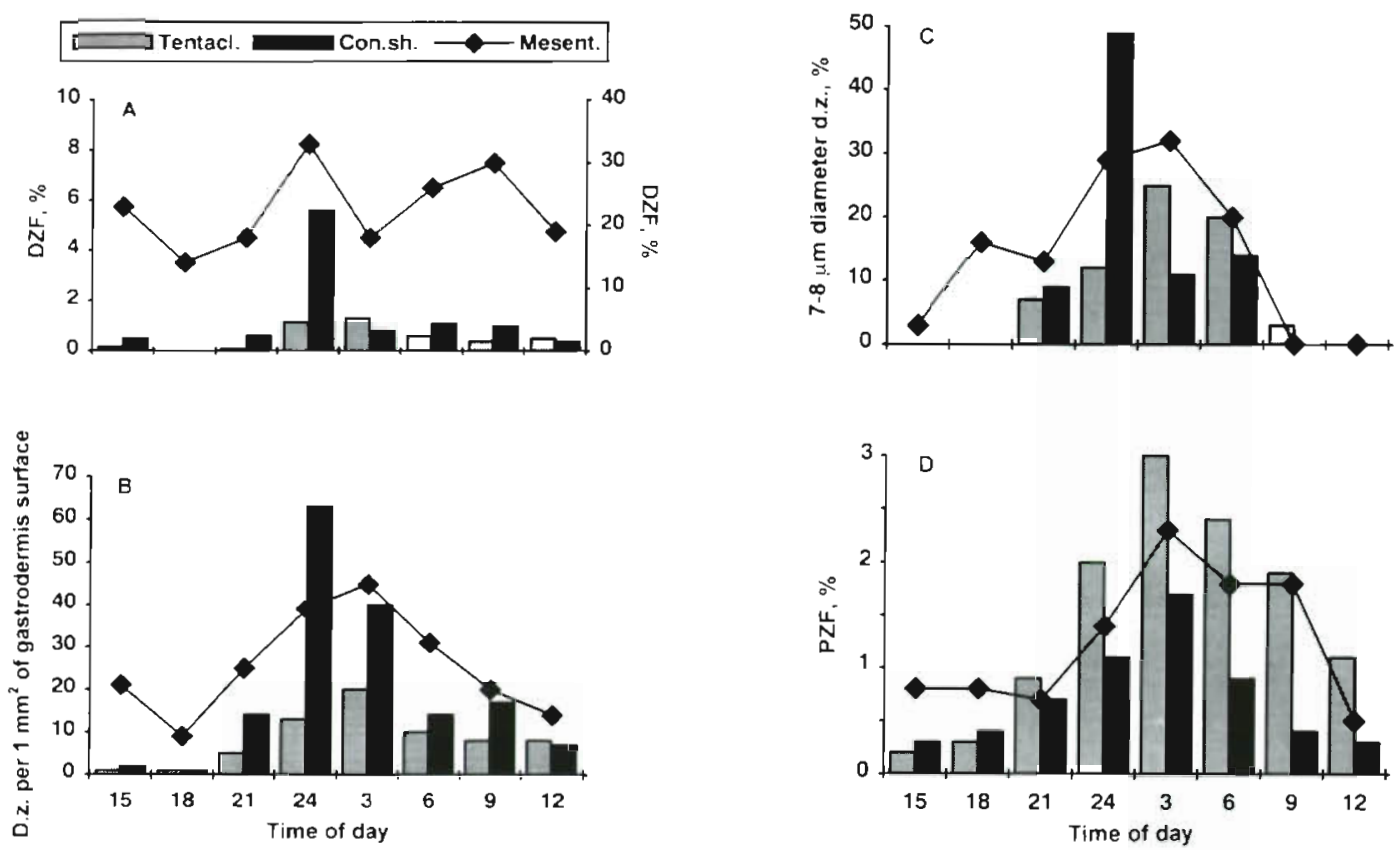

Fig. 2. Stylophora pistillata. Number of degraded and dividing cells in the connecting sheet (con. sh.), tentacles (tentacl.) and mesenteries (mesent.) during a day cycle. (A) Degraded zooxanthellae frequency (DZF) where the left-hand scale is for tentacles and connecting sheet and the right-hand scale is for mesenteries. (B) Degraded zooxanthellae (d.z.) density. (C) Percent d.z. with diameters 7 to $8 \mu \mathrm{m}$. (D) Proliferating zooxanthellae frequency (PZF)

highest density of d.z. was observed at 24:00 $\mathrm{h}$ in the connecting sheet and at 03:00 h in the tentacles and mesenteries. In $S$. pistillata tissue, the presence of 7 to $8 \mu \mathrm{m}$ diameter zooxanthellae indicated the commencement of the degradation process (Fig. 2C). In the connecting sheet and tentacles, the degradation process began at 21:00 h, and no further degradation was initiated after 09:00 h. In the mesenteries, degradation began earlier, at 15:00 h, and no further degradation occurred after 09:00 h.

Stylophora pistillata zooxanthellae divided mainly at night in all investigated tissues. PZF varied over the diel cycle: it was highest between 03:00 and 06:00 h and was lowest from 12:00 to 18:00 h. PZF also varied in accordance with location of tissue within the polyp: the highest means were within tentacles and the lowest within the connecting sheet.

\section{Release of d.z.p. and h.z.}

Fig. 3 shows the number of d.z.p. and h.z. released per $24 \mathrm{~h}$ period in colonies of Stylophora pistillata. Seriatopora caliendrum and Porites horizontalata. Each S. pistillata polyp released 50 to 1000 d.z.p. during $24 \mathrm{~h}$. Each $S$. caliendrum polyp released 100 to 2250 d.z.p. and each $P$. horizontalata released between 80 and 3300 d.z.p. during 24 h. Expulsion of h.z. in all 3 species was approximately 2 orders of magnitude
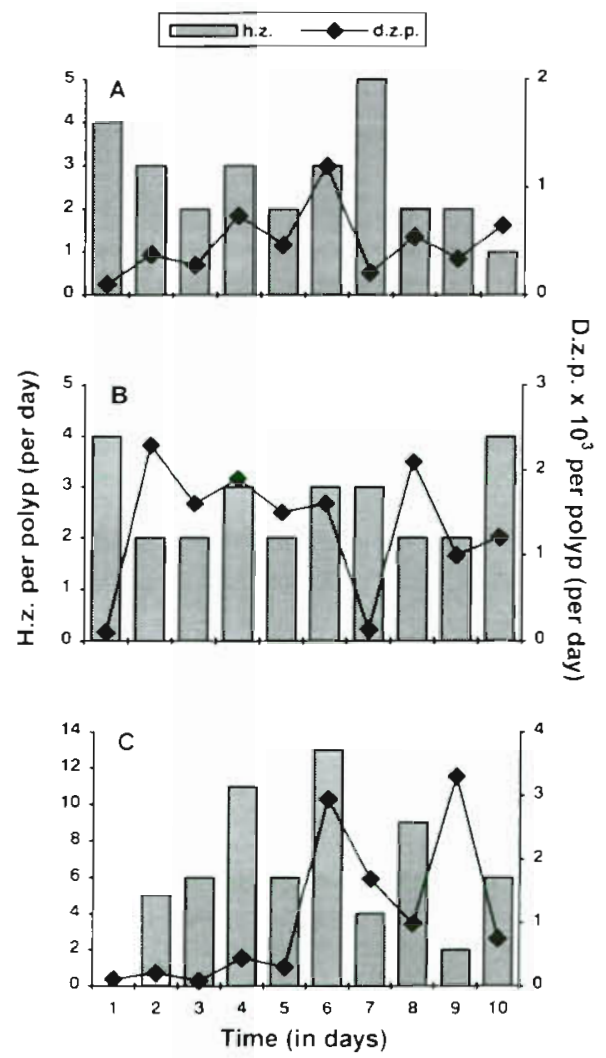

Fig. 3. (A) Stylophora pistillata, (B) Seriatopora caliendrum, and (C) Porites horizontalata. Daily release of degraded zooxanthellae particles (d.z.p.) and healthy-looking zooxanthellae (h.z.) 
lower, and amounted to 3 to 8 cells per polyp over $24 \mathrm{~h}$. There was a diurnal rhythm in the release of d.z.p., and generally the quantity of release alternated from high to low on consecutive days

The d.z.p. were released by polyps either as separate particles or as pellets (Fig. 4). The accumulation of individual d.z.p. and d.z.p. in pellets significantly differed during the course of the day. The quantity of individual d.z.p. slowly accumulated from 23:00 to 05:00-07:00 h and then rapidly increased from 07:00 to 11:00-13:00 h. The number of individual d.z.p. sharply decreased after 11:00 to 13:00 h. Generally, the number of d.z.p. pellets slowly increased from 23:00 to $15: 00 \mathrm{~h}$ and then rapidly increased from 15:00 to 21:00 h. Therefore, there was a simultaneous decrease in individual d.z.p. and sharp increase in pellet abundance.

Coral branches, as opposed to coral colonies, of Stylophora pistillata and Seriatopora caliendrum released mainly individual d.z.p. (Fig. 5). Pellet formation was non-existent. Particle release in both types of coral varied over the diel cycle but was highest between $12: 00$ and $15: 00 \mathrm{~h}$. During this time about $90 \%$ of the
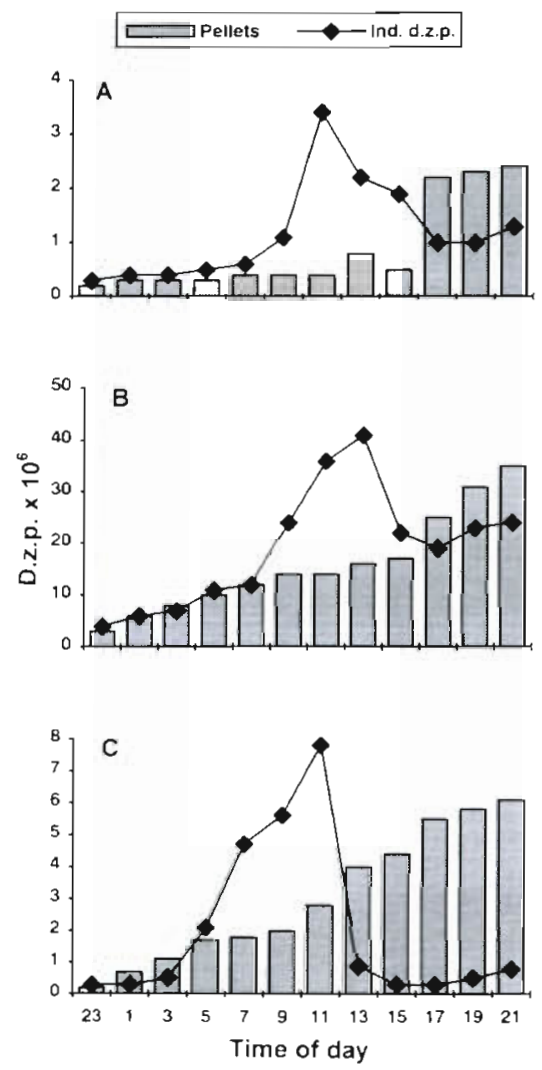

Fig. 4. (A) Stylophora pistillata, (B) Seriatopora caliendrum, and (C) Porites horizontalata. Accumulation of individual d.z.p. and pelleted d.z.p. in experimental glass jars over $24 \mathrm{~h}$

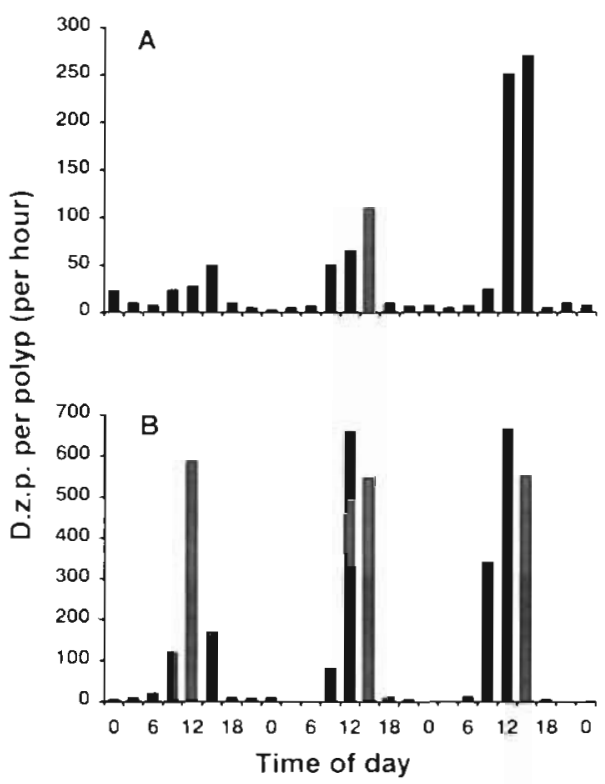

Fig. 5. (A) Stylophora pistillata and (B) Seriatopora caliendrum. Release rate of d.z.p. by coral branches over $3 \mathrm{~d}$

d.z.p. were released. In $S$. caliendrum the maximum rate of particle release (665 d.z.p. polyp ${ }^{-1} h^{-1}$ ) was 2.5 times higher than in $S$. pistillata.

Completely degraded zooxanthellae (4 to $5 \mu \mathrm{m}$ ) accumulated mainly in the body cavity of Stylophora pistillata (Fig. 6). Therefore, a higher number of d.z.p. were found in the coral gastroderm at night (from 24:00 to 06:00 h) than during the day. The accumulation of d.z.p. in the body cavity continued at night through to the early morning, that is, until the time of mass release (approximately to 12:00 h). Some d.z.p. remained in the body cavity (Fig. 6).

\section{Decrease of zooxanthellae density in S. pistillata under starvation}

Zooxanthellae density in coral branches maintained under starvation did not change during the first $8 \mathrm{~d}$ of the experiment. However, the density decreased to $66 \%$ on the 12 th day and to $16 \%$ on the 36 th day (Fig, 7A). Within the first week of starvation there were no significant changes to the DZF and PZF; they were, on average, similar and amounted to about $4 \%$ of the total content of zooxanthellae in the polyp tissue. After $12 \mathrm{~d}$ of starvation the DZF increased to $17 \%$, but the PZF did not change. A high DFZ level was maintained throughout the experiment, and a gradual decline of PZF, to $0.5 \%$, was evident after $36 \mathrm{~d}$ of starvation. The dynamics of d.z.p. release reflected the time course of degraded zooxanthellae frequency (Fig. 7C). Daily release of d.z.p. reached 1300 particles per polyp after 


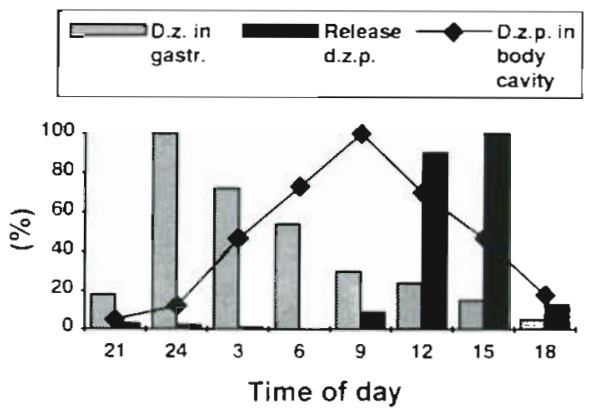

Fig. 6. Stylophora pistillata. Relative quantutaties (in terms of $\%$ of the maximum value of $\mathrm{d} . \mathrm{z}$. accumulation in the gastroderm (gastr.), d.z.p. in the body cavity and rate of d.z.p. release over $24 \mathrm{~h}$

$12 \mathrm{~d}$ of the experiment. The expulsion of healthy-looking zooxanthellae was insignificant and amounted to, on average, 10 to 20 cells polyp $\mathrm{p}^{-1} \mathrm{~d}^{-1}$ throughout the starvation experiment (Fig. 7C)
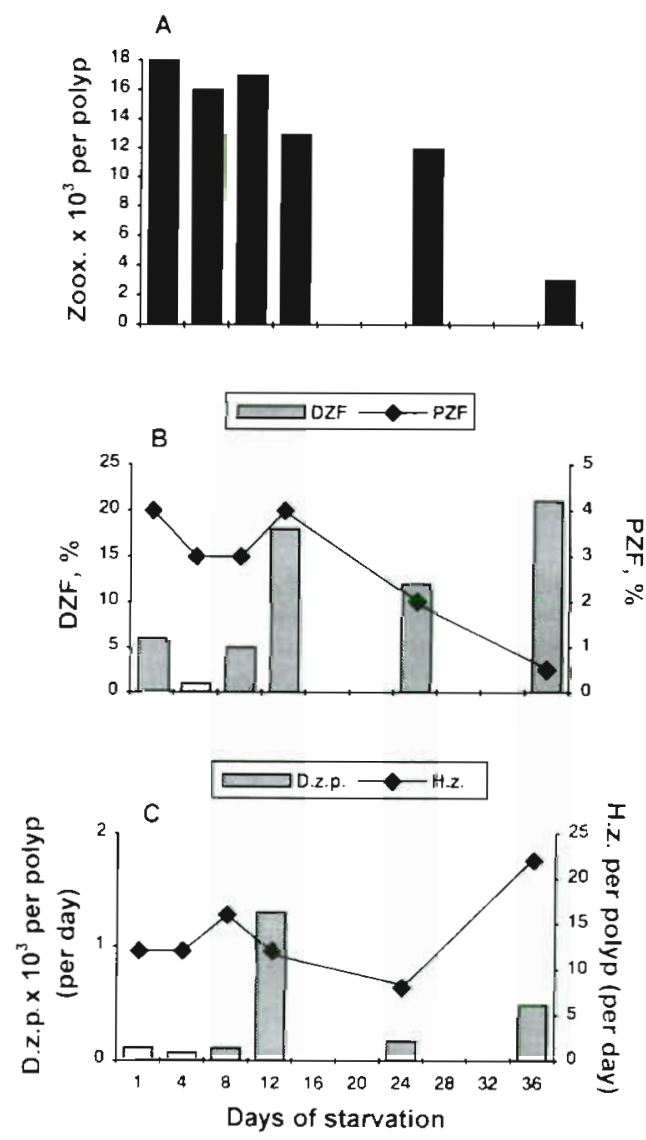

Fig. 7. Stylophora pistillata. (A) Zooxanthellae population density, (B) degraded (DZF) and proliferating (PZF) zooxanthellae frequency and (C) release of d.z.p. and h.z., as a function of days of starvation. Values represent the average for 3 coral branches

\section{DISCUSSION}

The proportion of degraded zooxanthellae in living tissue of the corals Millepora tenella, Montipora digitata, Pocillopora damicornis, Porites cylindrica, Porites horizontalata, Seriatopora caliendrum, Seriatopora hystrix and Stylophora pistillata amounted to 1 to $8 \%$. Boschma (1925) also reported on degraded zooxanthellae in Astrangia danae and detected that 'these algae are always found in the remains of the food in the gastric cavity'. Yonge \& Nichols (1931) while studying the effect of starvation on the relation between coral host and zooxanthellae also observed degraded zooxanthellae. Degraded zooxanthellae have been observed in bleached coral tissue subjected to elevated sea-water temperatures (Glynn et al. 1985, Hayes \& Bush 1990). Szmant \& Gassman (1990) also found abnormal zooxanthellae in the basal tissue of bleached Montastrea annularis. Recently, Brown et al. (1995) showed that the degradation of zooxanthellae is one of the mechanisms involved in coral bleaching, when water temperatures are higher than average $\left(1\right.$ to $2^{\circ} \mathrm{C}$ higher than seasonal maxima), with a possible synergetic effect of temperature and irradiance. A lot of disrupted and deformed zooxanthellae were detected in the gastroderm of both partially and fully bleached corals. Unbleached colonies also had degraded zooxanthellae in the mesenterial filaments, but not in other gastrodermal tissue (Brown et al. 1995).

In the present study, zooxanthellae in corals from shaded and well lit habitats were in all stages of ontogenesis, even in the stage of cell division (Fig. 1A), and the degraded zooxanthellae frequencies were similar to proliferating zooxanthellae frequencies. Therefore, under naturally constant conditions, the dividing process of symbiotic algae is probably in balance with degradation rates. In most cases, shaded habitats caused the accumulation of zooxanthellae, and values of degraded zooxanthellae frequency and proliferating zooxanthellae frequency decreased. In all cases the average diameter of a degraded zooxanthella was approximately half the size of a healthy zooxanthella. It is noteworthy that alga in Zoanthus sociatus (Anthozoa, Coelenterata), in the final stage of degradation, become reduced to approximately half their original diameter (Trench 1974)

Degraded zooxanthellae particles were expelled from the coral as individual particles or as pellets. The pellets contained mucus with over $90 \%$ d.z.p., and a small number of normal zooxanthellae. Steele \& Goreau (1977) observed the release of pellets consisting of healthy zooxanthellae and zooxanthellae debris from the sea anemone Phyllactis flosculifera. In tropical zoanthids of the genera Polythoa and Zoanthus, healthy zooxanthellae were expelled as a rolled fila- 
ment or 'zooxanthellar body' (Reimer 1971, see also Trench 1974), and in the sea anemone Aiptasia tagetes pellets are expelled containing almost exclusively healthy zooxanthellae, including dividing forms (Steele 1976). In Zoanthus sociatus, Trench (1974) described characteristics of degraded zooxanthellae similar to those described here in hermatypic corals. In the final stage of degradation this undigestable fragment contained a conglomerate of membranes derived from cell organelles and an 'accumulation body' (Trench 1974). Degraded symbionts of Phyllactis flosculifera and Zoanthus sociatus are seen only in the free edge in the former species and in the 'digestive-excretory' zone cells of the mesenteries in the latter (Trench 1974, Steele \& Goreau 1977), whereas, in hermatypic corals, degradation of zooxanthellae occurs in the gastroderm of the mesenteries, tentacles and connecting sheet.

The degradative process is phased and varied over the diel cycle in the gastroderm of hermatypic corals. During a $24 \mathrm{~h}$ period, approximately $30 \%$ of the zooxanthellae degrade in the mesenteries, around $6 \%$ in the connecting sheet and around $2 \%$ in the tentacles. Cell degeneration was highest at night and lowest during the day. Zooxanthellae degradtion took place only at night in the connecting sheet and tentacles, but both at night and during the day in the gastroderm of the mesenteries. Fitt \& Cook (1990) found a phased cycle of moribund zooxanthellae abundance, with a peak around midnight in the digestive cells of the marine hydroid Myrionema ambionense. In our experiments on Stylophora pistillata the highest frequencies of degraded zooxanthelae were found in the mesenteries, while the highest densities were found in the gastroderm of the connecting sheet. Considering the high level of degraded zooxanthellae frequencies found in the mesenteries, and their extended degeneration period, we are inclined to predict that the mesenterial gastroderm is a specialized place for zooxanthellae degradation. Although the number of healthy and degraded zooxanthellae are higher in the connecting sheet, the proportion of degraded zooxanthellae to healthy zooxanthellae was considerably lower than in the mesenteries.

Zooxanthellae proliferation also had a phased cycle in all gastroderm cells examined, with a peak around 03:00 h in close phase with the degradative process. Maximum proliferating zooxanthellae frequency was found in the tentacles $(3 \%)$ of Stylophora pistillata, and was lowest in the connecting sheet $(1.6 \%)$. In situ phased division of zooxanthellae is often seen in cnidarian hosts (including hermatypic corals) (Wilkerson et al. 1983, Smith \& Hoegh-Guldberg 1987. Hoegh-Guldberg \& Smith 1989).

A comparison of degraded zooxanthellae frequency and proliferating zooxanthellae frequency in the mesenteries showed that there was approximately $30 \%$ degradation during the day, and only $2.5 \%$ division. Taking this as a basis, it can be assumed that zooxanthellae are expelled into the body cavity (by exocytosis of the gastrodermal cells in the connecting sheet and tentacles), and then incorporated into the mesenteries (by phagocytosis of the gastroderm cells of the mesenteries). This is similar to the process described for Zoanthus sociatus by Trench (1974). It is noteworthy that the body cavity of Stylophora pistillata always contains a small number of healthy zooxanthellae within the polyps.

A schematic reconstruction of the possible pathways taken by zooxanthellae in Stylophora pistillata over the course of a day is depicted in Fig. 8. Degraded zoo-

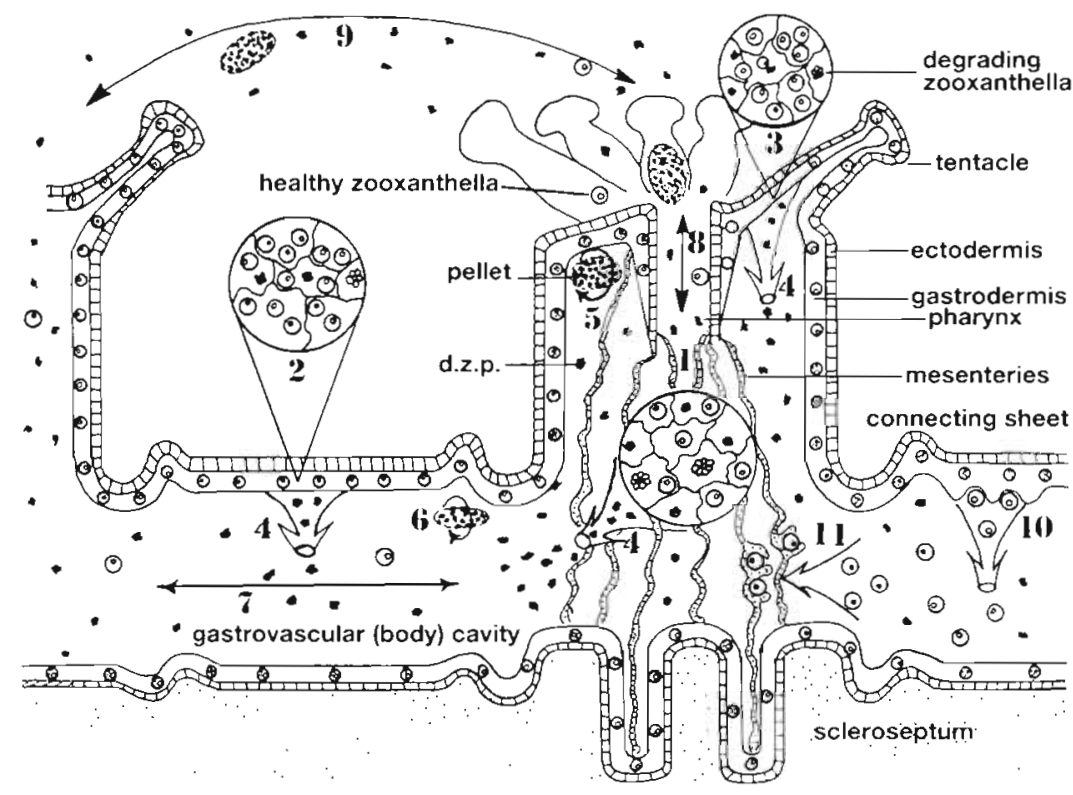

Fig. 8. Schematic representation of the zooxanthellae degradation process in Stylophora pistillata during $24 \mathrm{~h}$. (1) Degradation of zooxanthellae in the gastrodermis of the mesenteries (18:00 to $12: 00 \mathrm{~h}) .(2,3)$ Degradation of zooxanthellae in gastrodermis of the connecting sheet and tentacles, respectively (21:00 to 12:00 h). (4) Mass appearance of d.z.p. in the body cavity 6 h later and presence of abundant d.z.p. in the body cavity from 00:00 to 18:00 h. $(5,6)$ Formation of pellets from zooxanthellae debris, at the base of the tentacles and in the connecting sheet, respectively (09:00 to 15:00 h). (7) Possibility of transfer of d.z.p. from one polyp into another within the gastrovascular cavity. (8) Release of individual d.z.p. and pellets from the polyp. (9) Occasional migration of d.z.p. and pellets between polyps. (10) Possible exocytosis of zooxanthellae by gastroderm cells of the tentacles and connecting sheet. (11) Hypothetical phagocytosis of zooxanthellae by the mesenterial cells 
xanthellae are extruded from the gastrodermis and accumulate in the body cavity. The appearance of d.z.p. in the body cavity took place at 00:00-03:00 h, i.e. about $6 \mathrm{~h}$ after the first degraded cells appeared in the connecting sheet and tentacles. Therefore, the process of zooxanthellae degradation and extrusion of debris into the body cavity probably takes about $6 \mathrm{~h}$. Formation of pellets occurs mainly at the base of the tentacles and in the connecting sheet between the sclerosepta. The pellets appear to form by the rotation of debris, involving mucus, individual d.z.p. and a few h.z.

\section{Regulation of zooxanthellae population density by coral under starvtion}

Symbiont population densities decrease in corals under starvation (Yonge \& Nichols 1931, SzmantFroelich \& Pilson 1984). Meyer \& Schultz (1985) found that corals exposed to nutrients from fish excretion supported higher densities of zooxanthellae than colonies without resident fish. A comparison of fed and unfed sea anemones also displayed significant differences in algal densities (Clayton \& Lasker 1984, Cook et al. 1988).

In our experiments Stylophora pistillata lost $80 \%$ of its symbiont population over $36 \mathrm{~d}$ of starvation at 60 to $80 \%$ of surface irradiance. During the first $8 \mathrm{~d}$, the zooxanthellae densities did not decrease. Similarly, Cook et al. (1988) reported that zooxanthellae densities in Aiptasia pallida did not change during $10 \mathrm{~d}$ of starvation. In our experiments, algal density decreased only on the 12 th day of starvation, to approximately $70 \%$. On the same day, the degraded zooxanthellae frequency increased from 4 to $17 \%$, and the ratio of proliferating to degraded zooxanthellae frequency dropped from 1 to 0.25 on the 12 th day of the experiment. The number of released d.z.p. increased an order of magnitude. From the 12th. to 36th day of starvation the degraded zooxanthellae frequency and d.z.p. release rate remained high (but variable), and the proliferating zooxanthellae frequency dropped from $3-4 \%$ to $0.5 \%$. In the sea anemones (Cook et al. 1988 ) the mitotic index decreased from 8 to $1 \%$ after $30 \mathrm{~d}$ of starvation.

We suggest that Stylophora pistillata used the available resources of limited biogenic elements ( $N$ and $P$ ) over the first 8 to $10 \mathrm{~d}$ of starvation for the growth of animal tissue and for symbiont population replenishment, and then began to obtain these elements from zooxanthellae. Limiting the supply of biogenic elements to the zooxanthellae resulted in almost complete cessation of division. Our results with $S$. pistillata strengthen the widespread opinion that endosymbiotic algae in the invertebrate host utilize host metabolites as nutrient sources (e.g. Yonge \& Nichols 1931, Smith 1939. Cates \& McLaughlin 1979, Trench 1979, Steen 1986, Cook et al. 1988, McAuley 1994) and can be limited by $N$ and $P$ when the host is deprived of food (Cook et al. 1988, McAuley 1994). In the degradative process, zooxanthellae lost protein structures, nuclei and lipid drops. At the same time, the coral, which was deprived of food, lost more than half its zooxanthellae. Loss of zooxanthellae in $S$. pistillata during the food deprivation experiment was evidenced by zooxanthellae degradation and release of their remnants. Expulsion of healthy zooxanthellae, over the period starvation, was 2 orders of magnitude less than the d.z.p. release.

On this basis, we consider that the expulsion of h.z. under normal conditions is not important in the algal regulation process, and the principal mechanism whereby symbionts are eliminated is by degradation and release of debris. Under normal conditions, the host undoubtedly influences not only the zooxanthellae degradation process, but also their reproduction. Reproductive inhibition of zooxanthellae has also been shown to occur in sea anemones (Cook et al. 1988). As did Cook et al. (1988), we can only hypothesize that inhibition of coral symbiont reproduction occurs because the supply of nutrients stops. Other possibilities, such as inhibitor secretions, are not expected to be the cause (Muscatine \& Pool 1979, Trench 1987).

\section{Do hermatypic corals digest their own zooxanthellae?}

We are inclined to call the above process digestion of symbionts by the host because (1) the degradation process has a clear diel rhythm and occurs mainly at night, (2) zooxanthellae degradation occurs inside the animal gastrodermal cells; the gastrodermal cells of the mesenteries appear most specialized in the degradation process, (3) nuclei, protein structures, lipid drops and chl $c$ were not found within the zooxanthellae debris, and (4) the polyps regulate the intensity of algal degradation which is stimulated by a deficiency of food, and degradation is rapidly terminated upon reintroduction of food (Titlyanov unpubl.).

We didn't see the fusion of lysosome with zooxanthellae in polyp as was observed by Colley \& Trench (1985) in the polyp stage of the jellyfish Cassiopea xamachana and Fitt \& Cook (1990) in the marine hydroid Myrionema ambionense. However, in our opinion, under normal conditions, old or weak cells may be subject to autodegradation. In our case, as was stated above, even in the cell division stage, zooxanthellae were subjected to degradation. The process of digestion of zooxanthellae in hermatypic corals differs from that described by Trench (1974) in Zoanthus 
sociatus in which only senescent cells breakdown, and only in the digestive-excretory zone (as in a grave yard' for old defunct members of the algal population). However, in the present study, we observed digestion of apparently healthy zooxanthellae in the endoderm of the connecting sheet, tentacles and mesenteries. Digestion of coral symbionts is probably similar to the use of zooxanthellae as a nutrition source in the sea anemone Phyllactis flosculi (Steele \& Goreau 1977). A similar process of intracellular digestion has also been found in giant clams (Fankboner 1971) and in the marine hydroid Myrionema ambionense (Fitt \& Cook 1990). Infected symbionts are also digested by the protozoan Paramecium bursaria (Karakashian \& Karakashian 1973, Weis 1976) and by the polyp stage of the jellyfish Cassiopea xamachana (Colley \& Trench 1985). Therefore we conclude that the digestion of the algal symbionts by a coral host is a common process rather than a rare event.

Acknowledgements. The Russian authors thank the President of University of the Ryukyus, Keishin Sunagawa, for the invitation to work at Sesoko Station as visiting foreign researchers together with an accompanying person (T.V.T.). We are grateful to the staff for use of facilities, technical help and the atmosphere of friendship and confidence. Special thanks are due to our friend Prof. Y. Loya (Tel-Aviv University, Israel) for discussions on our work.

\section{LITERATURE CITED}

Boschma $H$ (1925) On the feeding reactions and digestion in the coral polyp Astrangia danae, with notes on its symbionts with zooxanthellae. Biol Bull Mar Biol Lab Woods Hole 49:407-439

Brown BE, Le Tissier MDA, Bythell JC (1995) Mechanisms of bleaching deduced from histological studies of reef corals sampled during a natural bleaching event. Mar Biol 122: $655-663$

Buddemeier RW, Fauti DG (1993) Coral bleaching as an adaptive mechanism. Bio Sci 43:320-326

Cates N, McLaughlin JJA (1979) Nutrient availability for zooxanthellae derived from physiological activities of Condulactus spp. J Exp Mar Biol Ecol 37:31-41

Clayton WS Jr, Lasker HR (1984) Host feeding regime and zooxanthellae photosynthesis in the anemone, Aiptasia pallida (Verrill.). Biol Bull Mar Bıol Lab Woods Hole 167 : $590-600$

Coles SJ, Fadlallah YH (1990) Reef coral survival and mortality at low temperatures in the Arabian Gulf: new speciesspecific lower temperature limits. Coral Reefs 9:231-237

Coles SJ, Jokiel PL (1978) Synergistic effects of temperature, salinity and light on the hermatypic coral Montipora verrucosa. Mar Biol 49:187-195

Colley NJ. Trench RK (1985) Cellular events in the reestablishment of a symbiosis between a marine dinoflagellate and coelenterate. Cell Tissue Res 239:93-103

Cook CB, D'Elia CF, Muller-Parker G (1988) Host feeding and nutrient sufficiency for zooxanthellae in the sea anemone Aiptasia pallida. Mar Biol 98:253-262

Cook CB, Fitt WK (1990) Some effects of dissolved inorganic nutrients in the hydroid Myrionema ambionense. In: Nar- don P, Gianinazzi-Pearson V. Grenier AM, Margulis L, Smith DC (eds) Endocytobiology. INRA, Paris, p 285-288 Fankboner PV (1971) Intracellular digestion of symbiotic zooxanthellae by host amoebocytes in giant clams (Bivalvia: Tridacnidae), with a note on the nutritional role of the hypertrophical siphonal epidermis. Brol Bull Mar Biol Lab Woods Hole 141:222-234

Fitt WK, Cook CB (1990) Some effect of host feeding on growth of zooxanthellae in the marine hydroid Myrionema ambionense in the laboratory and in nature. In: Nardon $P$. Gianınazzi-Pearson V, Grenier AM, Margulis L, Smith DC (eds) Endocytobiology IV. INRA, Paris, p 281-284

Gates RD (1990) Seawater temperature and sublethal coral bleaching in Jamaica. Coral Reefs 8:193-198

Gates RD, Baghdasarian G, Muscatine L (1992) Temperature stress causes host cell detachment in symbiotic Cnidarians: implications for coral bleaching. Biol Bull 182:324-332

Glider WV (1983) The biology of association of Symbiodinium microadriaticum with Ajptasia pallida: an anemone-alga symbiosis. PhD thesis, University of Nebraska, Lincoln

Glynn P (1990) Coral mortality and disturbances to coral reefs in the tropical eastern Pacific. In: Glynn PW (ed) Clobal ecological consequences of the 1982-83 EL-Nino Southern Oscillation. Elsevier, Amsterdam, p 55-126

Glynn PW, Peters EC, Muscatine L (1985) Coral tissue microstructure and necrosis: relation to catastrophic coral mortality in Panama. Dis Aquat Org 1:29-37

Goreau TF (1964) Mass expulsion of zooxanthellae from Jamaican reef communities after Hurricane Flora. Science 145:383-386

Hayes RL, Bush PG (1990) Microscopic observations of recovery in the reef-building scleractinian coral, Montastrea annularis after bleaching on a Cayman reef. Coral Reefs 8:203-209

Hoegh-Guldberg O, Mcrloskey LR, Muscatine L (1987) Expulsion of zooxanthellae from symbiotic Cnidarians from the Red Sea. Coral Reefs 7:113-116

Hoegh-Guldberg O, Smith GJ (1989) Influence of the population density of zooxanthellae and supply of ammonium on the biomass and metabolic characteristics of the reef corals Seriatopora hystrix and Stylophora pistillata. Mar Ecol Prog Ser 57:173-186

Hull HM, Hoshaw RW, Wang JC (1982) Cytofluorometric determination of nuclear DNA in living and preserved algae. Stain Technol 57:273-282

Jeffrey SW, Humphrey GP (1975) New spectrophotometric equations for determining chlorophylls $a, b, c_{1}$ and $c_{2}$ in higher plants, algae and natural phytoplankton. Biochem Physiol Pflanzen 167:191-194

Johannes RE, Wiebe WJ (1970) A method for determination of coral tissue biomass and composition. Limnol Oceanogr $21: 540-547$

Karakashian MW, Karakashian SJ (1973) Intracellular digestion and symbiosis in Paramecium bursaria. Expl Cell Res 81:111-119

McAuley PJ (1985) The cell cycle of symbiotic Chlorella. I. The relationship between host feeding and algal cell growth and division. J Cell Sci 77:225-239

McAuley PJ (1994) Interactions between host and symbionts in algal invertebrate intracellular symbioses. Bot $J$ Scotl $47(1): 97-112$

Meyer JL, Schultz ET (1985) Tissue condition and growth rate of corals associated with schooling fish. Limnol Oceanogr 30:157-166

Muller-Parker G (1984) Photosynthesis -irradiance responses and photosynthetic periodicity in the sea anemone Aiptasia pulchella. Mar Biol 82:225-232 
Muller-Parker G (1987) Seasonal variation in light-shade adaptation of natural populations of the symbiotic sea anemone Aiptasia pulchella (Carigren 1943) in Hawaii. J Exp Mar Biol Ecol 112:165-183

Muscatine L, McCloskey LR, Loya Y (1985) A comparison of the growth rates of zooxanthellae and animal tissue in the Red Sea coral Stylophora pistillata. Proc 5th Int Coral Reef Symp 6:119-123

Muscatine L, Pool RR (1979) Regulation of numbers of intracellular algae. Proc R Soc Lond B 204:131.-139

Pardy RL (1974) Some factors affecting the growth and distribution of the algal symbionts of Hydra viridis. Biol Bull Mar Biol Lab Woods Hole 147:105-118

Pardy RL, Muscatine L (1973) Recognition of symbiotic algae of Hydra viridis. A quantitive study of the uptake of living algae by aposymbiotic $H$. viridis. Biol Bull Mar Biol Lab Woods Hole 145:565-579

Pool RR (1976) Symbiosis of Chlorella and Chlorohydra viridissima. PhD dissertation, University of California, Los Angeles

Pool RR (1979) The role of algal antigenic determinants in the recognition of potential algal symbionts by cell of Chlorohydra. J Cell Sci 35:367-379

Reimer AA (1971) Observations on the relationships between several species of tropizoanthids (Zoanthidea, Coelenterata) and their zooxanthellae. J Exp Mar Biol Ecol 7 . $207-214$

Reynolds ES (1963) The use of lead nitrate at high $\mathrm{pH}$ as an electron opaque stain in electron microscopy. J Cell Biol $17: 208-212$

Smith DC, Muscatine L, Lewis DH (1969) Carbohydrate movement from autotrophs to heterotrophs in parasitic and mutualistic symbiosis. Biol Rev 44:17-90

Smith GJ, Hoegh-Guldberg $O$ (1987) Variation in the growth rate of zooxanthellae with coral host colony size is not controlled by changes in the duration of cytokinesis. EOS (Trans Am Geophys Un) 68:1724

Smith HG (1939) The significance of the relationship between actinians and zooxanthellae. J Exp Biol 16:334-345

Sorokin YI (1990) Coral reef ecosystems. Nauka, Moscow

Steele RD (1976) Light intensity as a factor in the regulation of the density of symbiotic zooxanthellae in Aiptasia tagetes. J Zool 179:387-405

Steele RD (1977) The significance of zooxanthellaecontaining pellets extruded by sea anemones. Bull Mar Sci 27:591-594

Steele RD, Goreau NI (1977) The breakdown of symbiotic zooxanthellae in the sea anemone Phyllactis (= Oulactis) flosculifera (Actiniaria). J Zool Lond 181:421-437

Steen RG (1986) Evidence for heterotrophy by zooxanthellae in symbiosis with Aiptasia pulchella. Biol Bull 170:267-278

Steen RG, Muscatine L (1987) Low temperature evokes rapid

This article was submitted to the editor exocytosis of symbiotic algae by a sea-anemone. Biol Bull $172: 246-263$

Stimpson J, Kinzie RA (1991) The temporal pattern and rate of release of zooxanthellae from the reef coral Pocillopora damicornis (Linnaeus) under nitrogen-enrichment and control conditions. J Exp Mar Biol Ecol 153:63-74

Szmant A, Gassman NJ (1990) The effects of prolonged 'bleaching' in the tissue biomass and reproduction of the reef coral Montastrea annularis. Coral Reefs 8:217-224

Szmant-Froelich A, Pilson EQ (1984) Effects of feeding frequency and symbiosis with zooxanthellae of nitrogen metabolism and respiration of the coral Astrangia danae. Mar Biol 81:153-162

Taylor DL (1969) On the regulation and maintenance of algal members zooxanthellae-coelenterate symbiosis, with a note on the nutritional relationship in Anemonia sulcata J Mar Biol Ass UK 49:1057-1065

Titlyanov EA, Zvalinsky VI, Leletkin VA, Shaposhnikova MG (1983) Zooxanthellae photosynthesis of reef-building corals in different light conditions. In: Krasnov EV (ed) Investigations on the Phantom Bank (Timor Sea). Far East Sci Center USSR, Vladivostok, p 51-74

Trench RK (1974) Nutritional potentials in Zoanthus sociatus (Coelenterata, Anthozoa). Helgol Wiss Meeresunters 26 $174-216$

Trench RK (1979) The cell biology of plant-animal symbiosis A Rev Plant Physiol 30:485-531

Trench RK (1987) Dinoflagellates in non-parasitic symbiosis In: Taylor FJR (ed) The biology of dinoflagellates. Blackwell Scientific Press, Oxford, p 531-570

Van Woesik R, De Vantier LM, Glazebrook JS (1995) Effects of cyclone 'Joy' on nearshore coral communities of the Great Barrier Reef. Mar Ecol Prog Ser 128:261-270

Weis DS (1976) Digestion of added homologous algae by Chlorella-bearing Paramecium bursaria. J Protozool 23(4): $527-529$

Wilkerson RP, Muller-Parker G, Muscatine L (1983) Temporal patterns of cell division in natural populations of endosymbiotic algae. Limnol Oceanogr 28:1009-1014

Williams EH Jr, Bunkley-Williams L (1990) The world-wide coral reef bleaching cycle and related sources of coral mortality. Atoll Res Bull 335:1-71

Yamazato K (1981.) A note on the expulsion of zooxanthellae during summer, 1980 by the Okinawan reef-building corals. Sesoko Mar Sci Lab Tech Rep 8:9-18

Yonge CM (1931) Studies on the physiology of corals. III Assimilation and excretion. Scjent Rep Gt Barrier Reef Exped 1:11-91

Yonge CM. Nichols AG (1931) Studies on the physiology of corals. $V$. The effect of starvation in light and in darkness on the relationship between corals and zooxanthellae. Scient Rep Gi Barrier Reef Exped 1:177-211

Manuscript first received: November 18, 1995

Revised version accepted: March 21, 1996 